\title{
Efficiency of Selected Sudanese Sheep Markets: A Multivariate Approach (1995-2011)

\author{
Mohamed Bushara $\mathrm{OA}^{1 *}$ and Murtada KA Abdelmahmod ${ }^{2}$
}

${ }^{1}$ Faculty of Agricultural Sciences, University of Gezira, Wad Medani, Sudan

${ }^{2}$ Faculty of Management Sciences and Economics, Department of Economics, University of AL-Butana, Rufaa, Sudan

\begin{abstract}
The main objective of this study is to investigate price movements among important sheep markets in the Sudan to explore their pricing efficiency. The short period of long-run equilibrium adjustment indicated that there are strong price linkages between Omdurman and other four markets (Elobied, Medani, Sennar and Nyala markets). The prices causality indicated unidirectional relation causality of Nyala market through Medani and Elobied markets. Nyala markets as terminal market located in production area Granger cause Medani and Omdurman as major consumption markets; this was taken as evidence that price movements were primarily driven by supply shocks. That mean the system was centred on Nyala i.e. Nyala could be considered as a supply market in sheep market which means the prices were supply driven.
\end{abstract}

Keywords: Market efficiency; Sheep; Multivariate cointegration; Sudan

\section{Introduction}

\section{Background}

The global economy witnessed a number of economic and financial crises since the late of $19^{\text {th }}$ and early of $20^{\text {th }}$ century, which caused a decline in consumption and private sector investment, rise in unemployment rate and slowdown in economic growth rates.

The global financial crisis of 2008, discerned with banking crisis, instability of foreign exchange and imbalances in stock markets. As the result of linkage between the international financial markets, their adverse effects outreached the performance of the international financial markets and the real sector through the slackening demand for goods and services. This engendered a decline in their prices, including oil prices during the last quarter of 2008.

The government plan toward agricultural development is to invest a part of oil revenues for the activation of agricultural sectors and to boost production to achieve the aspirations and economic goals, especially the creation of the economic boom in exports of nonpetroleum resources like agriculture and livestock [1]. Unfortunately, slight progress in performance of the agricultural sector, relatively attributed to the implementing some of the development programs and the downturn in the animal resources section. In the additional; (1) reasons of this section drop is obvious the agriculture sector shares are still little and humble revenues with unstable shift, and (2) the overall state for all items of exports of non-petroleum products didn't attain the desired share of the export revenue or promote the state of the trade balance which has recently become out of deficit circle at the beginning of the year 2007 as shown in Table 1.

Table 1 above indicates high surplus with value of 2.456 Billion US\$ in 2010 compared with surplus in 2008, 2007 with value $2.319,1.1$ million US\$ respectively. In the last decade the government has sought to increase exports of livestock and livestock products. Sudan's livestock exports fell dramatically in 2000-2001, however, when Saudi Arabia and other Gulf countries temporarily banned imports of live animals from Sudan [2]. Since 2002 Sudan's livestock exports have rebounded, but they constitute a smaller part of non-oil exports than during the 1990s. In 2005, oil accounted for $82 \%$ of Sudan's total exports by value; livestock and livestock products were just 3-2\%of exports by value (or nearly $18 \%$ by value of non-oil exports).

In 2003 President Al-Bashir issued a set of directives to spur livestock exports, putting the Ministry of Foreign Trade in charge of re-organizing and improving Sudan's livestock markets. In November 2003 the Ministry directed the creation of a pilot Cattle Auction Project at El Muwelih market in Omdurman [3]. This project would require payment in cash at the time of transaction and sale by weight and open auction, theoretically improving the overall efficiency and transparency of the marketing system [4]. If the project succeeds at El Muwelih it would be replicated at other livestock markets, but for now, the auction project is stalled owing to problems in organizing financial services to facilitate cash payments.

Sudan is among the richest African countries in term of size of its national herds. The livestock population keeps increasing through the years, in the year 2010 the livestock population comprised about 42 million cattle, 4.623 million camels, 52 million sheep and 43 million goats as presented in Table 2 below.

\begin{tabular}{|l|l|l|l|l|l|}
\hline Period & $\begin{array}{l}\text { Petroleum } \\
\text { export }\end{array}$ & $\begin{array}{l}\text { Non-petroleum } \\
\text { export }\end{array}$ & Total export & $\begin{array}{l}\text { Total } \\
\text { import }\end{array}$ & $\begin{array}{l}\text { Trade } \\
\text { balance }\end{array}$ \\
\hline 2005 & 4187.360 & 636.918 & 4824.278 & 6756.820 & $(1932.542)$ \\
\hline 2006 & 5087.211 & 569.357 & 5656.568 & 8073.498 & $(2416.930)$ \\
\hline 2007 & 8418.258 & 460.722 & 8879.250 & 8775.457 & 1027.93 \\
\hline 2008 & 11094.111 & 576.393 & 11670.502 & 9351.540 & 2318.964 \\
\hline 2009 & 7131.255 & 702.441 & 7833.696 & 9690.918 & $(1857.222)$ \\
\hline 2010 & 9905.248 & 1377.351 & 11282.779 & 8839.400 & 2456.000 \\
\hline
\end{tabular}

Source: (Sudan, 2012).

Table 1: The trade balance (U.S.A Million Dollar) during the period 2005-2010).

*Corresponding author: Bushara MOA, Faculty of Agricultural Sciences University of Gezira, Wad Medani, Sudan, Tel: +249129771033; E-mail: mosman@uofg.edu.sd

Received October 30, 2016; Accepted November 11, 2016; Published November 16,2016

Citation: Mohamed Bushara OA, Abdelmahmod MKA (2016) Efficiency of Selected Sudanese Sheep Markets: A Multivariate Approach (1995-2011). Int J Econ Manag Sci 6: 389. doi: 10.4172/2162-6359.1000389

Copyright: (c) 2016 Mohamed Bushara OA, et al. This is an open-access article distributed under the terms of the Creative Commons Attribution License, which permits unrestricted use, distribution, and reproduction in any medium, provided the original author and source are credited. 


\begin{tabular}{|l|l|l|l|l|}
\hline Year & Cattle & Camel & Sheep & Goats \\
\hline 1995 & 30077 & 2903 & 37146 & 33319 \\
\hline 1996 & 31669 & 2915 & 37202 & 35215 \\
\hline 1997 & 33102 & 2936 & 39835 & 36037 \\
\hline 1998 & 34584 & 2974 & 42363 & 36498 \\
\hline 1999 & 35825 & 3031 & 44802 & 37346 \\
\hline 2000 & 35093 & 3108 & 46095 & 38952 \\
\hline 2001 & 38325 & 3203 & 47043 & 39952 \\
\hline 2002 & 39479 & 3342 & 48136 & 41485 \\
\hline 2003 & 39669 & 3503 & 48440 & 42030 \\
\hline 2004 & 39760 & 3724 & 48910 & 42179 \\
\hline 2005 & 40468 & 3908 & 49797 & 42526 \\
\hline 2006 & 40994 & 4078 & 50390 & 42756 \\
\hline 2007 & 41138 & 4238 & 50651 & 42938 \\
\hline 2008 & 41426 & 4406 & 51067 & 43104 \\
\hline 2009 & 41563 & 4521 & 51555 & 43270 \\
\hline 2010 & 41761 & 4623 & 52079 & 43441 \\
\hline
\end{tabular}

Source: (Statistics, 2009).

Table 2: Livestock population (000 head) 1995-2010).

Sudan's economy is one of the fastest growing in the world. Since 1999, the country is taking advantage of vast oil reserves receiving large inflows of foreign direct investment. Yet, in spite of abundance of natural resources; agriculture remains an important sector of the economy as it contributes a third of GDP. More importantly, years of civil wars, lack of infrastructure, and a reliance on subsistence agriculture has made the majority of Sudanese to live below the poverty line.

The main livestock production sites are located far from the major consumption centres and export outlets. Economically valuable livestock populations are concentrated in northern, western and southern Kordofan and Darfur. Blue Nile and Elgadarif states are also important supply places for export sheep [5].

Allocating sheep efficiently over space should faster a sustainable use of pasture resources. It is also expected to favour the sharing of risk across regions by smoothing price variation. Thus, studying coinegration of sheep is important for optimal resource use, early warning and market and trade policy [6].

Livestock have historically been central to Sudan's overall economy, although in recent years oil production has become the dominant feature of the political economy of Sudan. Since 1999, livestock and livestock products (meat, hides and skins) have comprised approximately $20 \%$ of Sudan's annual Gross Domestic Product (Sudan, 2010). As oil production has increased, however, the relative importance of livestock and livestock product for exports as foreign exchange earners had declined. In 2005 oil was 82\% (by value) of total exports while livestock and livestock product exports were just 3.2\%. The international Monetary Fund attributes the recent decline in livestock exports to "supply constraints (inadequate capacity at the port, deterioration in the road infrastructure), conflict in livestock-rich areas, and higher domestic demand".

Most researchers agree that the problems of livestock marketing in Sudan are limited to the specific problems which could be summarized in a weak infrastructure especially in the area of transport and veterinary services, lack of finance led to oligopoly and oligopsony in the trade, areas of production distant from areas of consumption and together with lack of suitable transport render animals weak and meat quality low, smuggling especially across the borders to Egypt and Libya and lack of veterinary services.
One of the main problems of livestock marketing is that, the livestock markets approach is the sellers dominated market. According to ref. [7], the main constraints to animals marketing include poor marketing infrastructure, lack of marketing organization, lack of market intelligence, absence of marketing extension services and absence of grades and standards. The main problems indicated by the herders include shortage of drinking water, spread of animals' diseases, and lack of veterinary services and encroachment of agricultural activities on grazing land.

\section{The problem statement}

Despite the significant importance of sheep to Sudanese economy but its markets still not well developed. The main constraints to animals marketing include poor market infrastructure, lack of market organization, lack of market intelligence, inadequacy of market finance, shortage of drinking water, spread of animals diseases, and lack of veterinary services and transport services, these constrains are affecting marketing efficiency.

\section{The questions of the study}

To achieve the objectives of this study, the following questions need to be answered:

1. Are sheep prices data in the Sudan have stationary properties over time?

2. Is sheep price shock that happens in one market affecting the other markets?

3. Are the sheep markets integrated?

4. Is there any cointegration between these markets in the short and long run?

\section{The objectives of study}

The main objective of this paper is to investigate sheep markets in the Sudan to explore their price efficiency.

From the mentioned research problem the following sub-objectives are distinguished:

1. To investigate sheep market integration through analyzing price variation in selected markets.

2. To outline some policy recommendations, that might help policy makers to draw plans to improve the livestock marketing system.

\section{Data and Methodology}

The study focused on scrutinizing the sheep markets in Sudan by considering the prices of five livestock markets which were Elobied, Omdurman, Medani, Sennar and Nyala. The study covered the periods from January 1995 to December 2011. The data used in these prices were monthly prices which have been collected from the Animal Resources Company; these prices were wholesale price i.e. the selling price of a head of animal measure in Sudanese Pound (SDG). To attain the cointegration analysis the data should be in real terms to avoid spurious regression, so all price series were deflated by GDP deflator rather than consumer price index. The deflated prices data were transformed in term of natural logarithm so as to attain a constant variance in the series, and then this logged deflated prices data used in the empirical analysis [8]. See Figures 1-3 for visual appreciation. 


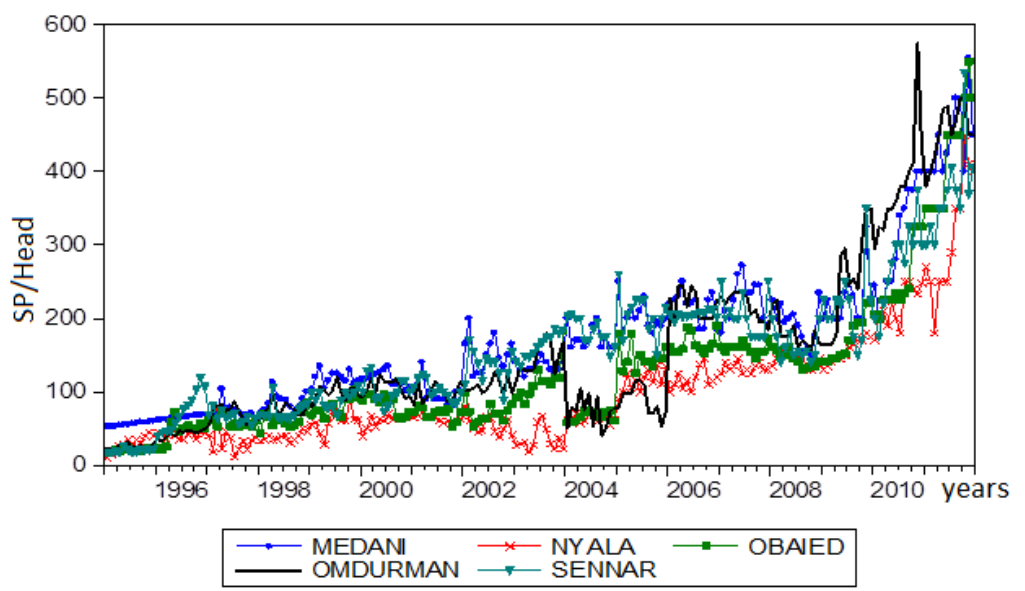

Figure 1: Monthly nominal wholesale price (Sudanese pound per head) of camels in the selected markets, January 1995 - December 2011

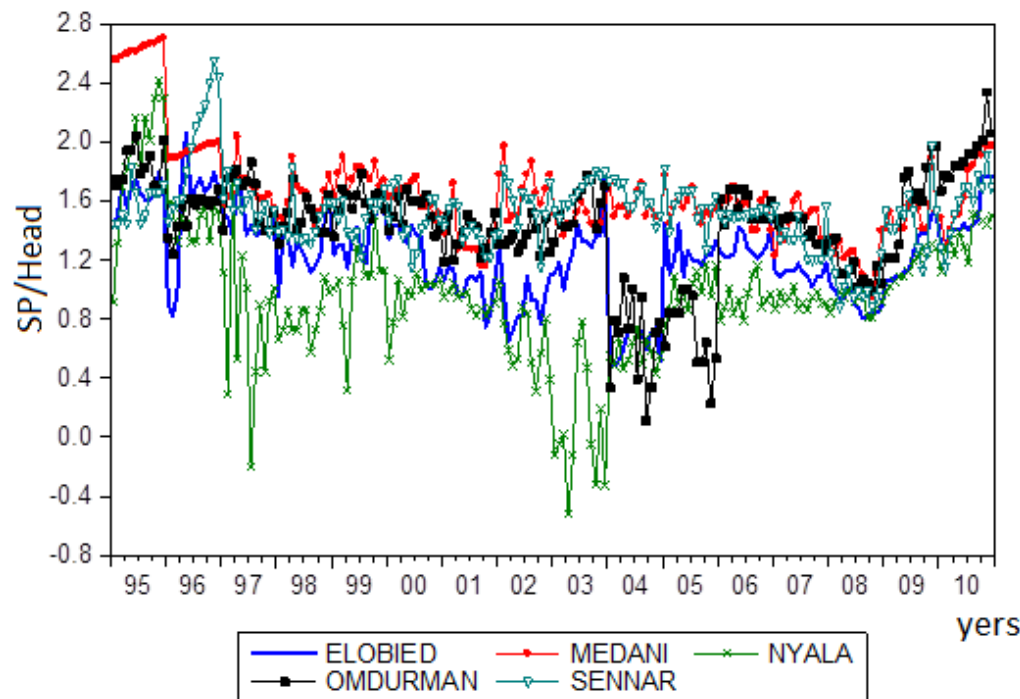

Figure 2: Monthly deflated wholesale price (Sudanese pound per head) of sheep in the selected markets, January 1995 - December 2011.

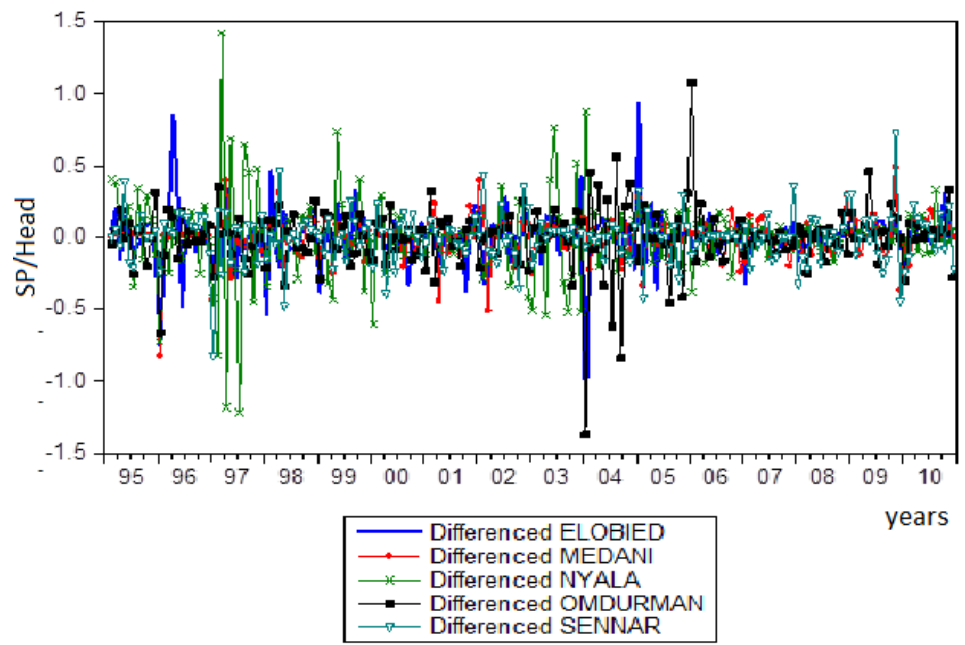

Figure 3: First difference of monthly deflated wholesale price (Sudanese pound per head) of sheep in the selected markets, January 1995 - December 2011. 
Johansen Maximum likelihood ratio approach:

Johansen's methodology takes its starting point in the vector auto regression (VAR) of order $p$ given by:

$$
Y_{t}=u+A_{1} y_{t-1}+\ldots+A_{p} y_{t-p}+\varepsilon_{t}
$$

Where $\mathrm{y}_{1}$ is a $k$-dimension vector of variables which are assumed to be $\mathrm{I}(1)$ series (but could also be $\mathrm{I}(0)$ ), $\mathrm{Ai}, \mathrm{I}=1, p$ is the coefficient matrix, and $\varepsilon_{\mathrm{t}}$ is a $k$-dimension vector of residuals. Subtracting $\mathrm{y}_{\mathrm{t}-1}$ from both sides of equation (1) yields:

$$
\Delta y_{t}=u+\prod y_{t-1}+\Gamma_{1} \Delta y_{t-1}+\ldots+\Gamma_{p-1} \Delta y_{t-p+1}+\varepsilon_{t}
$$

This VAR can be re-written as:

$$
\begin{aligned}
& \Delta y_{t}=u+\prod y_{t-1}+\sum_{i=1}^{p-1} \Gamma_{i 1} \Delta y_{t-i}+\varepsilon_{t} \\
& \text { Where } \Pi=\sum_{i=1}^{p} A_{i}-1 . \\
& \text { and } \Gamma_{1}=\sum_{j=i+1}^{p} A_{j} .
\end{aligned}
$$

From equation (3) the only one term in the equation, $\mathrm{IIy}_{\mathrm{t}-\mathrm{e}}$, is in levels, cointegration relations depend crucially on the property of matrix II. It is clear that IIy $y_{t-1}$ must be either I(0) or zero except that $\mathrm{y}_{\mathrm{t}}$ is already stationary. There are three situations:

(a) II $=\boldsymbol{\alpha} \boldsymbol{\beta}^{\prime}$ has a reduced $\operatorname{rank} 0<\mathrm{r}<\mathrm{k}$,

(b) II $=\boldsymbol{\alpha} \boldsymbol{\beta}^{\prime}$ has a rank of zero, and

(c) II $=\boldsymbol{\alpha} \boldsymbol{\beta}^{\prime}$ has a full rank.

Under situation (a), $\alpha$ and $\beta$ are both $k x r$ matrices and have a rank of $r$. There are $r$ cointegration vectors $\beta$ 'yt which are stationary $I(0)$ series. It is equivalent to having $r$ common trends among $y_{t}$. The stationarity of $\beta^{\prime} y t$ implies a long-run relationship among $y_{t}$ ar a sub-set of $y_{t}$ the variables in the cointegration vectors will not depart from each other over time. $\beta^{\prime} y_{t}$ are also error correction terms in that departure of individual variables in the cointegration vectors from the equilibrium will be subsequently reversed back to the equilibrium, a dynamic adjustment process called error correction mechanism (ECM). Equation (3) is therefore called VAR with ECM. Under situation (b), there is no cointegration relation among $y_{t}$ and the variables in levels do not enter equation (3), and then equation (3) becomes a simple VAR without ECM. The variables in levels are already stationary under situation (c).

Johansen proposes two different likelihood ratio tests of the significance of these canonical correlations and thereby the reduced rank of the II matrix: the trace test and maximum eigenvalue test, shown in equations (6) and (7) respectively.

\section{The trace statistic test}

The trace statistic test the null hypothesis of $r$ cointegrating relations against the alternative of $\mathrm{k}$ cointegrating relations, where $\mathrm{k}$ is the number of endogenous variables, for $r=0,1,, \mathrm{k}-1$. The alternative of $k$ cointegrating relations corresponds to the case where none of the series has a unit root and a stationary VAR may be specified in terms of the levels of all of the series. The trace statistic for the null hypothesis of $r$ cointegrating relations is computed as:

$$
\pi_{\text {trace }}(r / k)=-T \sum_{i=r+1}^{n} h\left(1-\hat{\lambda}_{i}\right) .
$$

Where $\lambda_{\mathrm{I}}$ is the $i$-th largest eigenvalue of the matrix in (4) and (5).

\section{The maximum eigenvalue statistic test}

The second test is maximum eigenvalue statistic which tests the null hypothesis of $(r)$ cointegrating relations against the alternative of $(1+r)$ cointegrating relations. This test statistic is computed as:

$$
\pi_{\text {max }}(r / r+1)=-\operatorname{TIn}\left(1-\hat{\lambda}_{r+1}\right) .
$$

Neither of these test statistics follows a chi square distribution in general; asymptotic critical values could be found in Johansen and Juselius [9] and are also given by most econometric software packages. Since the critical values used for the maximum eigenvalue and trace test statistics are based on a pure unit-root assumption, they would no longer be corrected when the variables in the system are near - unitroot processes. By default, E-views program reports the value based on MacKinnon et al., [10] p-values for Johansen's cointegration trace test and maximum eigenvalue test.

\section{Results and Discussion of the Multivariate Cointegration Approach for Sheep}

This section presents the results of the second cointegration analysis approach which is the system based tests using the vector autoregression (VAR) of Johansen $[11,12]$ in which the joint effects of prices in all markets in concern were accounted for.

\section{The order of vector autoregressive models}

A major requirement in conducting $[13,14]$ cointegration tests and estimation of a VAR system, either in its unrestricted or restricted Vector Error Correction (VEC) forms, is the choice of an optimal lag length. Noting that, the lag length ought to be set long enough to ensure that the residuals are white noise and considering that the study was based on monthly data. The lag structure of the estimated VAR was then examined using a combination of VAR lag order selection information criteria [15] (AIC), Bayesian (SBC), likelihood ratio (LR) and [16] (HQ) information criterion) and checking that the inverse roots of the characteristic polynomial lie within a unit circle, which is a condition for having a stable VAR system. This process led to the choice of two lags as shown in Table 3, which was used in the cointegration test and subsequent analysis.

According to Table 3 below while the SC and HQ criteria suggested the use of one lag, the AIC and LR criterion suggests the use of two lags which was used in the cointegration test and subsequent analyses.

\begin{tabular}{|l|l|l|l|l|l|l|}
\hline Lag & LogL & LR & FPE & AIC & SC & HQ \\
\hline 0 & -103.5315 & NA & $2.08 \mathrm{e}-06$ & 1.107464 & 1.191090 & 1.141320 \\
\hline 1 & 308.6366 & 799.1014 & $4.01 \mathrm{e}-08$ & -2.843230 & $-2.341478^{\star}$ & $-2.640097^{\star}$ \\
\hline 2 & 337.0304 & $53.60052^{*}$ & $3.87 \mathrm{e}-08^{\star}$ & $-2.877861^{*}$ & -1.957982 & -2.505450 \\
\hline 3 & 351.9707 & 27.44142 & $4.30 \mathrm{e}-08$ & -2.775211 & -1.437205 & -2.233522 \\
\hline 4 & 367.3639 & 27.48779 & $4.75 \mathrm{e}-08$ & -2.677182 & -0.921049 & -1.966216 \\
\hline 5 & 384.4530 & 29.64446 & $5.17 \mathrm{e}-08$ & -2.596459 & -0.422200 & -1.716215 \\
\hline 6 & 402.7316 & 30.77512 & $5.57 \mathrm{e}-08$ & -2.527873 & 0.064513 & -1.478351 \\
\hline 7 & 416.1288 & 21.87298 & $6.31 \mathrm{e}-08$ & -2.409477 & 0.601036 & -1.190677 \\
\hline 8 & 437.4491 & 33.72091 & $6.62 \mathrm{e}-08$ & -2.371930 & 1.056711 & -0.983852 \\
\hline
\end{tabular}

indicates lag order selected by the criterion.

LR: LR test statistic (each test at $5 \%$ level).

FPE: Final Prediction Error.

AIC: Akaike Criterion.

SC: Schwarz Criterion.

$H Q$ : Hannan-Quinn information criterion.

Table 3: Vector autoregressive (VAR) lag order selection criteria. 
Examination of the inverse roots of the AR characteristic within the unit circle for the VAR specification indicates that a VAR satisfies the stability condition under using two lag. i.e. if the estimated VAR process is stationary, then all AR roots should lie inside the unit circle as showing in Table $4 \mathrm{a}$ and Figure 2 below. No root lies outside the unit circle. VAR satisfies the stability condition.

The stationary condition for general AR (p) processes is that the inverted roots of the lag polynomial lie inside the unit circle. There is no particular problem if the roots are imaginary, but a stationary AR model should have all roots with modulus less than one. From Table $4 \mathrm{a}$ above the roots computed for six lag corresponding to that VAR lag order selection criteria, and they were all less than one. This indicates that VAR satisfies the stability condition. An inverse root of AR characteristic polynomial is measuring of stability of the VAR model. According to Greene and Seaks [17] the estimated VAR is stable (stationary) if all roots have modulus less than one and lie inside the unit circle. If the VAR is not stable, certain results (such as impulse response standard errors) are not valid. Inverse roots of AR characteristic polynomial graphed in Figure 4 confirm the stability condition of the VAR model and enable to perform the impulse response analysis.

\section{Number of cointegration vectors for sheep prices}

Following the result of the previous stage was used to determine the cointegrating vectors in the models on the maximum eigenvalue, the trace of the stochastic matrix test of and the three model selection criteria i.e. HQC, SBC and AIC were also used. Table $4 \mathrm{~b}$ below displays the result of Johansen likelihood ratio test. In this table the null hypothesis of no cointegration $(\mathrm{r}=0)$ among variables was rejected in both trace test statistic and the maximum eigenvalue statistic. The trace of stochastic matrix (80.60235) and the maximum eigenvalue statistic (34.01498) were above their corresponding 95\% critical values of (69.81889) and (33.87687) respectively. Moreover, a hypothesis of numbers of cointegration vector in trace test under two forms, which

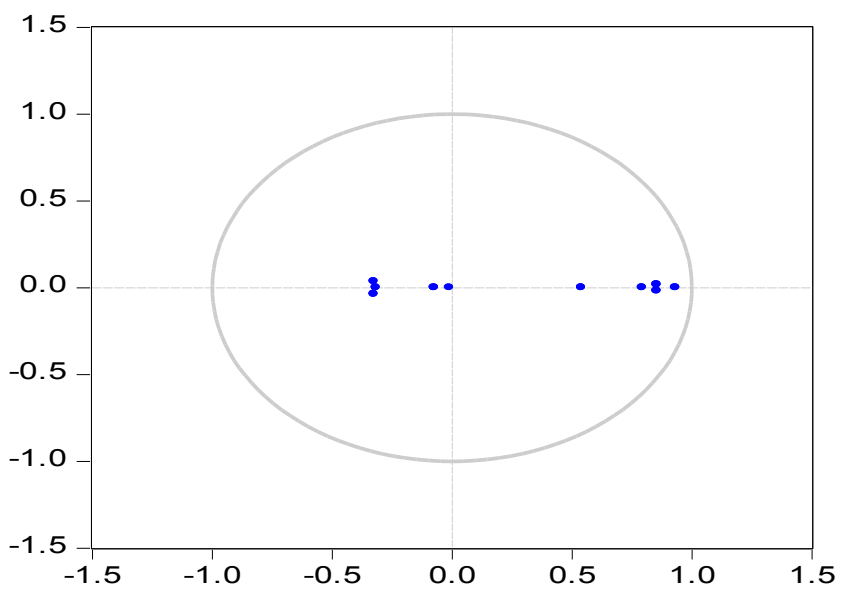

Figure 4: Inverse roots of AR characteristic polynomial.

\begin{tabular}{|c|c|}
\hline Root & Modulus \\
\hline 0.931192 & 0.931192 \\
\hline 0.793502 & 0.793502 \\
\hline 0.540547 & 0.540547 \\
\hline-0.315481 & 0.315481 \\
\hline-0.073369 & 0.073369 \\
\hline-0.010658 & 0.010658 \\
\hline
\end{tabular}

Table 4a: Roots of characteristic polynomial.

\begin{tabular}{|l|l|l|l|l|}
\hline $\begin{array}{l}\text { Hypothesized } \\
\text { No. of CE(s) }\end{array}$ & Eigenvalue & Trace statistic & $\begin{array}{l}\mathbf{0 . 0 5} \text { critical } \\
\text { value }\end{array}$ & Prob.** \\
\hline None* & 0.155684 & 80.60235 & 69.81889 & 0.0054 \\
\hline At most 1 & 0.081920 & 46.58737 & 47.85613 & 0.0655 \\
\hline At most 2 & 0.071724 & 29.40775 & 29.79707 & 0.0554 \\
\hline At most 3 & 0.056180 & 14.44816 & 15.49471 & 0.0714 \\
\hline At most 4 & 0.013963 & 2.826300 & 3.841466 & 0.0927 \\
\hline
\end{tabular}

Trace test indicates 1 cointegrating equation(s) at the 0.05 level.

* denotes rejection of the hypothesis at the 0.05 level.

**(MacKinnon, Haug, and Michelis, 1998) p-values.

Table 4b: Johansen tests results for number of cointegrating vector, sheep prices 1995 M1 - 2011 M 12

\begin{tabular}{|l|l|l|l|l|}
\hline $\begin{array}{l}\text { Hypothesized } \\
\text { No. of CE(s) }\end{array}$ & Eigenvalue & $\begin{array}{l}\text { Max-Eigen } \\
\text { statistic }\end{array}$ & $\begin{array}{l}\mathbf{0 . 0 5} \text { critical } \\
\text { value }\end{array}$ & Prob. ${ }^{* *}$ \\
\hline None* & 0.155684 & 34.01498 & 33.87687 & 0.0482 \\
\hline At most 1 & 0.081920 & 17.17961 & 27.58434 & 0.5646 \\
\hline At most 2 & 0.071724 & 14.95960 & 21.13162 & 0.2917 \\
\hline At most 3 & 0.056180 & 11.62186 & 14.26460 & 0.1257 \\
\hline At most 4 & 0.013963 & 2.826300 & 3.841466 & 0.0927 \\
\hline
\end{tabular}

Max-eigenvalue test indicates 1 cointegrating equation(s) at the 0.05 level. ${ }^{*}$ Denotes rejection of the hypothesis at the 0.05 level.

**(MacKinnon, et al. 1998) p-values.

Table 5: Maximum eigenvalue test.

\begin{tabular}{|l|l|l|l|l|l|}
\hline & Elobied & Medani & Nyala & Omdurman & Sennar \\
\hline Elobied (-1) & 0.613060 & 0.090410 & 0.311431 & 0.091187 & 0.032881 \\
& $(7.54994)$ & $(1.50239)$ & $(2.78297)$ & $(1.03904)$ & $(0.46372)$ \\
\hline Elobied (-2) & 0.043154 & -0.078070 & -0.151306 & 0.017438 & 0.084813 \\
& $(0.52055)$ & $(-1.27070)$ & $(-1.32434)$ & $(0.19462)$ & $(1.17159)$ \\
\hline Medani (-1) & 0.007900 & 0.628405 & 0.141660 & -0.020018 & 0.083183 \\
& $(0.07254)$ & $(7078563)$ & $(0.94381)$ & $(-0.17006)$ & $(0.87467)$ \\
\hline Medani (-2) & -0.021268 & 0.228341 & 0.065291 & -0.042489 & -0.045833 \\
& $(-0.20168)$ & $(2.92185)$ & $(0.44928)$ & $(-0.37281)$ & $(-0.49774)$ \\
\hline Nyala (-1) & 0.154580 & 0.126781 & 0.513116 & 0.131704 & 0.069027 \\
& $(2.95996)$ & $(3.27577)$ & $(7.12946)$ & $(2.33339)$ & $(1.51367)$ \\
\hline Nyala (-2) & -0.082681 & -0.115860 & 0.227576 & -0.061898 & -0.080753 \\
& $(-1.61179)$ & $(-304763)$ & $(3.21912)$ & $(-1.11645)$ & $(-1.80278)$ \\
\hline Omdurman (-1) & 0.110607 & 0.073261 & $-0-072923$ & 0.563890 & -0.024555 \\
& $(1.58830)$ & $(1.41954)$ & $(-0.75984)$ & $(7.49206)$ & $(-0.40379)$ \\
\hline Omdurman (-2) & 0.024560 & -0.039209 & 0.061472 & 0.246778 & -0.018017 \\
& $(0.35387)$ & $(-076229)$ & $(0.64268)$ & $(3.28979)$ & $(-0.29728)$ \\
\hline Sennar (-1) & 0.091231 & 0.019972 & -0.085149 & 0.000184 & 0.605897 \\
& $(1.00669)$ & $(0.29737)$ & $(-068177)$ & $(0.00188)$ & $(7.65647)$ \\
\hline Sennar (-2) & $2.53 E-05$ & -0.038050 & -0145744 & -0.032725 & 0.111546 \\
& $(0.00028)$ & $(-056697)$ & $(-1.16785)$ & $(-0.33437)$ & $(1.41066)$ \\
\hline R-squared & 0.707018 & 0.816817 & 0.714716 & 0.734693 & 0.604287 \\
\hline F-statistic & 46.09166 & 85.16735 & 47.85076 & 52.89212 & 29.16726 \\
\hline
\end{tabular}

Table 6: Vector autoregression (VAR) estimates for sheep prices.

is at most one cointegration relation was found $(r=1)$ and at most two cointegration relations were found $(r=2)$ was rejected at $5 \%$ significant level while it was accepted in hypothesis $(\mathrm{r}=3)$. Therefore, the trace of stochastic matrix indicates three cointegrating equations at the 0.05 significant levels while the maximum eigenvalue test suggested one cointegration relation.

According to Banerjee [18] and Dickey and Fuller, if any divergence of results between these two tests. (The maximum eigenvalue Table 5 and the trace tests Table $4 \mathrm{~b}$ exits, it is advisable to rely on the eigenvalue test since the results of the latter test are more reliable in small samples. If rely in this argument, the sheep price data in Sudan (1995 ml $2011 \mathrm{~m} \mathrm{12}$ ) appears a stable long run relationship and suggested one cointegration vector. 


\section{Estimation of vector autoregressive (VAR) model for sheep}

The lag structure of the estimated VAR was examined using a combination of VAR lag order selection information criteria with two lag length as indicated in Table 6 before. The results of the VAR model are presented in the following Table 6.

Each column in the table corresponds to an equation in the VAR. For each right-hand side variable it was reported the estimated coefficient and the t-statistic. For example, the coefficient for Elobied on Medani (-1) equation is $(0.00790)$. The numbers at the very bottom of the table are the summary statistics for the VAR system as R-squared and F-statistic.

To examine the results presented in Table 6 above, collectively, the results significant according to the standard $F$ test for each model which were (46.09166), (85.16735), (47.85076), (52.89212) and (29.16726) for Elobied, Medani, Nyala, Omdurman and Sennar models respectively. By considering the first equation of Elobied variable, only Elobied at lag one and Nyala at lag one month was statistically significant. The sings of the significant vector autoregression in the Elobied model suggest that, an increase in the level of Elobied lag one month leads to an increase in the level of prices of Nyala lag one month.

Turning to Medani equation, only Medani at lag two is statistically significant according to $t$-statistic. According to the Omdurman equation, only Nyala at lag one and Omdurman itself at lag two were statistically significant according to $t$-statistic. That means the prices of sheep in Nyala and Omdurman itself in the two previous months affected the prices of Omdurman in the current month. The positive coefficient sings explained the positive relationship between Omdurman and Nyala prices.

Sennar market affected just by its own prices in the previous month and no other market affected it. Nyala equation shows that the prices of sheep effected by its own prices in the previous two months and affected by the prices of Elobied market in the previous month.

\begin{tabular}{|l|l|l|l|l|l|}
\hline Error correction & $\mathbf{D}$ (Elobied) & $\mathbf{D}($ Omdurman) & $\mathbf{D}($ Medani) & $\mathbf{D}($ Sennar) & $\mathbf{D}$ (Nyala) \\
\hline D(Elobied (-1)) & -0127281 & 0.001576 & 0.105428 & -1.121850 & 0.162604 \\
& $(-1.42999)$ & $(0.01605)$ & $(1.55952)$ & $(-1.53336)$ & $(1.34313)$ \\
\hline D(Elobied (-2)) & -0.109718 & 0.007629 & 0.014907 & $-0.023880)$ & -0.045370 \\
& $(-1.32665)$ & $(0.08362)$ & $(0023732)$ & $(-0.32341)$ & $(-0.40333)$ \\
\hline D(Omdurman (-1)) & 0.003431 & -0.353459 & 0.068439 & 0.069326 & -0.035194 \\
& $(0.04679)$ & $(-4.37004)$ & $(1.22900)$ & $(1.05906)$ & $(-0.35291)$ \\
\hline D(Omdurman (-2)) & 0.024603 & -0.132673 & 0.042277 & 0.064557 & -0.059205 \\
& $(0.34907)$ & $(-1.70639)$ & $(0.78978)$ & $(1.02594)$ & $(-0.61761)$ \\
\hline D(Medani (-1)) & 0.063939 & -0.021296 & -0.325814 & 0.023383 & 0.187121 \\
& $(0.58112)$ & $(-0.17545)$ & $(-3.89883)$ & $(0.23804)$ & $(1.25037)$ \\
\hline D(Medani (-2)) & -0.075011 & -0.165601 & -0.165229 & -0.007078 & 0.245021 \\
& $(-0.97988)$ & $(-1.36061)$ & $(-1.97178)$ & $(-0.07186)$ & $(1.63277)$ \\
\hline D(Sennar (-1)) & -0.058338 & 0.079296 & 0.003859 & -0.204802 & 0.034977 \\
& $(-0.62177)$ & $0.76612)$ & $(0.05415)$ & $(-2.44490)$ & $(0.27409)$ \\
\hline D(Sennar (-2)) & -0.064432 & 0.080315 & -0.041397 & -0.126953 & -0.247774 \\
& $(-0.70397)$ & $(0.79544)$ & $(-0.59550)$ & $(-1.55359)$ & $(-1.99030)$ \\
\hline D(Nyala (-1)) & 0.077171 & 0.104987 & 0.124884 & 0.115226 & -0.442197 \\
& $(1.47797)$ & $(1.82269)$ & $(3.14909)$ & $(2.47177)$ & $(-622651)$ \\
\hline D(Nyala (-2)) & -0.064141 & -0.017767 & 0.010852 & 0.015668 & -0.278784 \\
& $(-1.22032)$ & $(-0.30642)$ & $(0.27183)$ & $(0.33388)$ & $(-3.89963)$ \\
\hline R-squared & 0.162374 & 0.167111 & 0.137007 & 0.146324 & 0.244208 \\
\hline F-statistic & 3.330701 & 3.447366 & 2.727750 & 2.945050 & 5.551695 \\
\hline Table & & &
\end{tabular}

Table 7: Vector error correction estimates (short run dynamics matrix $(\Gamma)$ ) for sheep.

\section{Estimating vector error correction (VECM) model for sheep}

After obtaining the order of vector autoregressive models, the number of cointegration vectors and estimation of vector autoregressive (VAR) model results, the next stage in the model building process requires the construction of a multivariate VECM for sheep prices in Elobied, Omdurman, Medani, Sennar and Nyala where the time series were found to be cointegrated. Using information constructed from above results, one cointegration vector and one lag lengths were imposed in estimation of Vector Error Correction (VECM) Model and the long and short run matrices were extracted and presented in Table 7 below. These matrices describe the system dynamics.

\section{Cointegration short run dynamics matrices $(\Gamma)$ for sheep}

The short run test results reported in Table 7 which presents the short run matrix for sheep prices in selected markets. Again as the Vector Autoregression (VAR) estimates result in Table 6, each column in the table corresponds to an equation in the VECM (short run dynamics). For each right-hand side variable, E-views report the estimated coefficient and the t-statistic.

Elobied sheep prices were not affected by any other market price as shown in the first column. The second column in the table shows that Omdurman market was affected just by its own prices and affected by Nyala prices in the previous month, but according to F-statistics Omdurman market not affected by all other markets in the short run. Medani sheep prices affected by own prices and by Nyala market prices in the short run.

The fourth equation shows that Sennar is affected by its own prices in the previous month and by Nyala prices lag one month also. Nyala market equation shows two significant coefficients that are Nyala itself in the previous two month and Sennar lagged one month. The linkages between markets are presented in Figure 5 below.

Omdurman, Medani and Sennar were affected by their own prices and affected just by Nyala market, while Elobied market seems to be separated from the other markets, this due to feature of this market which considered as export market. Idris [19] states that the prices of sheep offered for export is higher and affect the mean prices of sheep at El Khewi. For this reason, the purchasing and the selling prices of sheep are lower in Omdurman rather than El Khewi and Elobied.

\section{Cointegration long run equilibrium matrices (II) for sheep prices}

The long run equilibrium matrices (II) describe the long run effect. These matrices are extracted from the error correction models presented in Table 8 below:

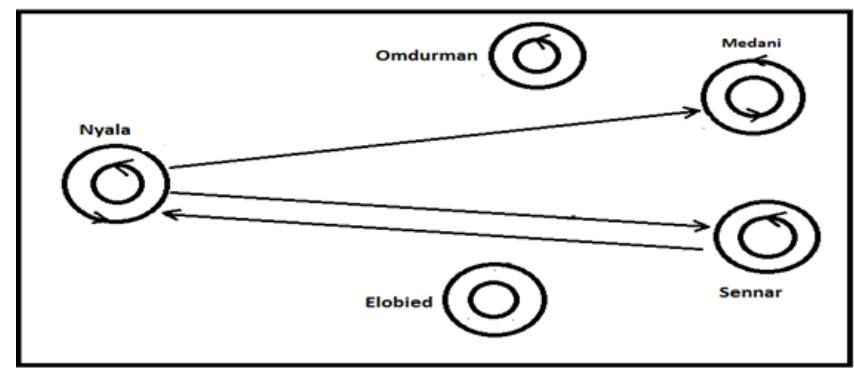

Source: drawing using vector error correction estimates, Table 7.

Figure 5: Lines connected multivariate sheep markets whose prices were cointegrated in the short run, $1995 \mathrm{ml}-2011 \mathrm{ml}$. 


\begin{tabular}{|l|l|l|l|l|l|}
\hline & Medani & Elobied & Omdurman & Sennar & Nyala \\
\hline D(Medani) & -0.009646 & -0.028988 & 0.014982 & 0.007746 & 0.024697 \\
& $(-0.51706)$ & $(-0.51706)$ & $(0.51706)$ & $(0.51706)$ & $(0.51706)$ \\
\hline D(Elobied) & $-0.073358)$ & -0.220464 & 0.113947 & 0.058910 & 0.187828 \\
& $(-2.98665)$ & $(-2.98665)$ & $(2.98665)$ & $(2.98665)$ & $(2.98665)$ \\
\hline D(Omdurman) & 0.030327 & 0.091141 & -0.047105 & -0.024354 & -0.077649 \\
& $(1.11924)$ & $(1.11924)$ & $(-1.11924)$ & $(-1.11924)$ & $(-1.11924)$ \\
\hline D(Sennar) & 0.059705 & 0.179432 & -0.092737 & -0.047946 & -0.152871 \\
& $(2.72266)$ & $(2.72266)$ & $(-2.72266)$ & $(-2.72266)$ & $(-2.72266)$ \\
\hline D(Nyala) & 0.056699 & 0.170399 & -0.088068 & -0.045532 & -0.145175 \\
& $(1.69719)$ & $(1.69719)$ & $(-1.69719)$ & $(-1.69719)$ & $(-1.69719)$ \\
\hline
\end{tabular}

Table 8: Cointegration long run equilibrium matrices (II) for sheep prices - 1995 $\mathrm{ml}-2011 \mathrm{~m} 12$.

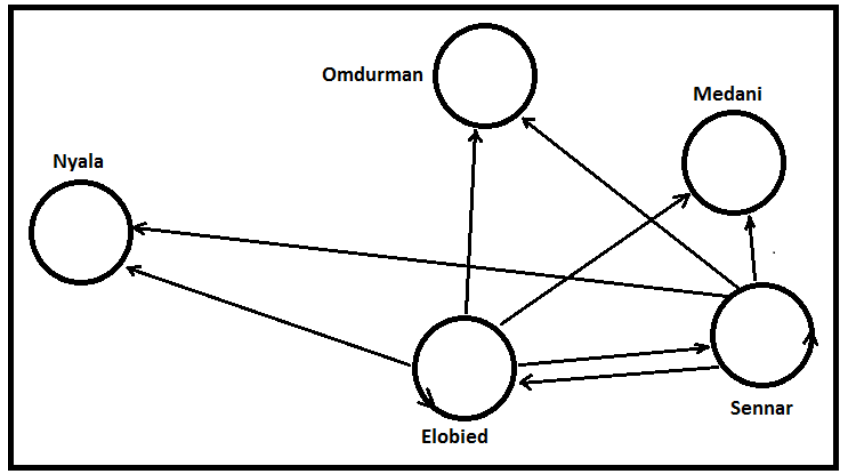

Source: drawing using the long run equilibrium matrix (II) Table 8

Figure 6: Lines connected sheep markets whose prices were cointegrated in the long run, $1995 \mathrm{ml}-2011 \mathrm{~m} 12$.

As evident in Table 8 the error correction terms have been found to be statically significant in Elobied and Sennar markets indicating that, the level of sheep prices in Elobied and Sennar exert significant long run effect on the current development of prices of Medani, Elobied, Omdurman, Sennar and Nyala markets, suggesting the validity of the long run equilibrium relationship in Elobied and Sennar markets. But the levels of sheep prices in the other five markets have no significant long run effect on Omdurman, Medani and Nyala prices.

- Note: the coefficients in bold font are significant at 0.05 significant levels.

- The figures in parentheses are the t-ratio for the estimates.

- D stand for the changes in the variables in concern.

- Source: Calculated from appendix (B) using E-views software computer program.

The sings of the significant error correction terms suggest that the increase in the level of Omdurman, Sennar and Nyala prices in the long run leads to an increase in the level in Elobied sheep market and decrease in the level of Sennar sheep prices, while an increase in the level of Elobied itself and Medani prices in the long run leads to decrease in the level of Elobied sheep prices market and increase in the level of Sennar prices market. Figure 6 below presents these linkages between markets.

The figure shows that Omdurman, Medani and Nyala markets were not cointegrated. The lack of cointegration among these markets because of the long distances separating the major sheep production areas from the consumption areas, the slow means of transport and communication and the high marketing costs are the main reasons for this phenomenon. The trekking route from Nyala to Elobied, for instance, is about 600 kilometers, and that between Elobied and Omdurman is about 560 kilometers [20], giving a total trekking route from Nyala to Omdurman of about 1.160 kilometers. The journey along this route takes 75 to 80 days, making the total marketing costs about $24 \%$ of the total costs. The error correction model takes into account the adjustment of long-run disequilibrium in markets and time to remove disequilibria in each period.

Table 8 shows that $5-22 \%$ of disequilibrium is removed in each period. For example, for the prices of Elobied market about $7 \%$ of the disequilibrium is removed in Medani in one month, while for the prices of Sennar market about $6 \%$ of the disequilibrium is removed in Medani in one month.

\section{Diagnostic tests}

In order to select an ECM, it needs to satisfy a range of diagnostic tests. These diagnostics provide information about the data properties and evaluate restrictions on the estimated coefficients, including the special case of tests for omitted and redundant variables. The diagnostic tests usually include Lagrange multiplier test for autocorrelation, Ramsey's "RESET" test for functional form, normality and. The results of diagnostic tests of sheep prices data in Table 9 are robust as they satisfy almost all relevant diagnostic tests. But with respect of Elobied, the models suffere from normality problem as indicated in Jarque-Bera test p-value (0.34676) [21] which failed to reject the null hypotheses of non-normal distribution. One possible explanation for this problem is

\begin{tabular}{|c|c|c|c|c|}
\hline Equation & $\begin{array}{l}\text { Lagrange } \\
\text { multiplier test }\end{array}$ & $\begin{array}{l}\text { Ramsey's } \\
\text { RESET }\end{array}$ & $\begin{array}{l}\text { Jarque-Bera } \\
\text { test }\end{array}$ & ARCH test \\
\hline Elobied & $\begin{array}{l}42.32270 \\
(0.0000)\end{array}$ & $\begin{array}{l}3.481716 \\
(0.0327)\end{array}$ & $\begin{array}{l}2.11823 \\
(0.34676)\end{array}$ & $\begin{array}{l}27.58053 \\
(0.0000)\end{array}$ \\
\hline Omdurman & $\begin{array}{l}88.59090 \\
(0.0000)\end{array}$ & $\begin{array}{l}11.34216 \\
(0.0000)\end{array}$ & $\begin{array}{l}126.2270 \\
(0.0000)\end{array}$ & $\begin{array}{l}34.71072 \\
(0.0000)\end{array}$ \\
\hline Medani & $\begin{array}{l}128.0405 \\
(0.0000)\end{array}$ & $\begin{array}{l}9.138076 \\
(0.0002)\end{array}$ & $\begin{array}{l}36.84919 \\
(0.0000)\end{array}$ & $\begin{array}{l}74.2400 \\
(0.0000)\end{array}$ \\
\hline Sennar & $\begin{array}{l}104.7137 \\
(0.0000)\end{array}$ & $\begin{array}{l}75.73425 \\
(0.0000)\end{array}$ & $\begin{array}{l}19.91321 \\
(0.00005)\end{array}$ & $\begin{array}{l}90.63660 \\
(0.0000)\end{array}$ \\
\hline Nyala & $\begin{array}{l}67.08509 \\
(0.0000)\end{array}$ & $\begin{array}{l}2.631351 \\
(0.0745)\end{array}$ & $\begin{array}{l}116.6391 \\
(0.0000)\end{array}$ & $\begin{array}{l}16.43895 \\
(0.0000)\end{array}$ \\
\hline
\end{tabular}

Table 9: Diagnostic test results for the estimated equations of sheep prices, (19952011).

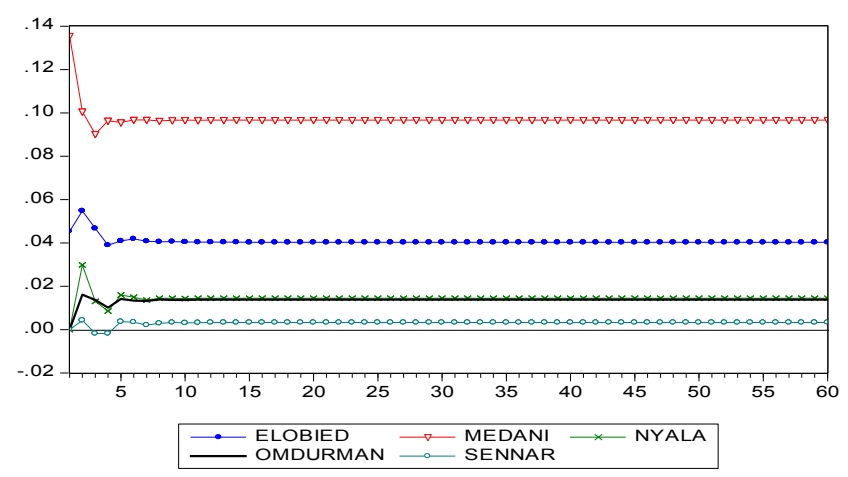

- $\quad \mathrm{Y}$ axis is stander error (SD).

$\mathrm{X}$ axis is months.

Figure 7: Generalized impulse response to one standard error shock in the equation of Medani sheep prices $1995 \mathrm{ml}-2011 \mathrm{~m} 12$. 


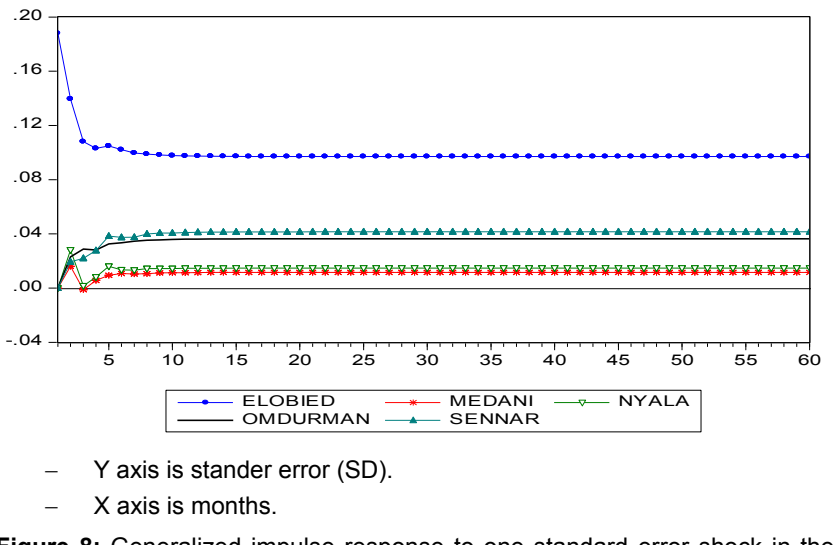

Figure 8: Generalized impulse response to one standard error shock in the equation of Elobied sheep prices $1995 \mathrm{ml}-2011 \mathrm{~m} 12$.

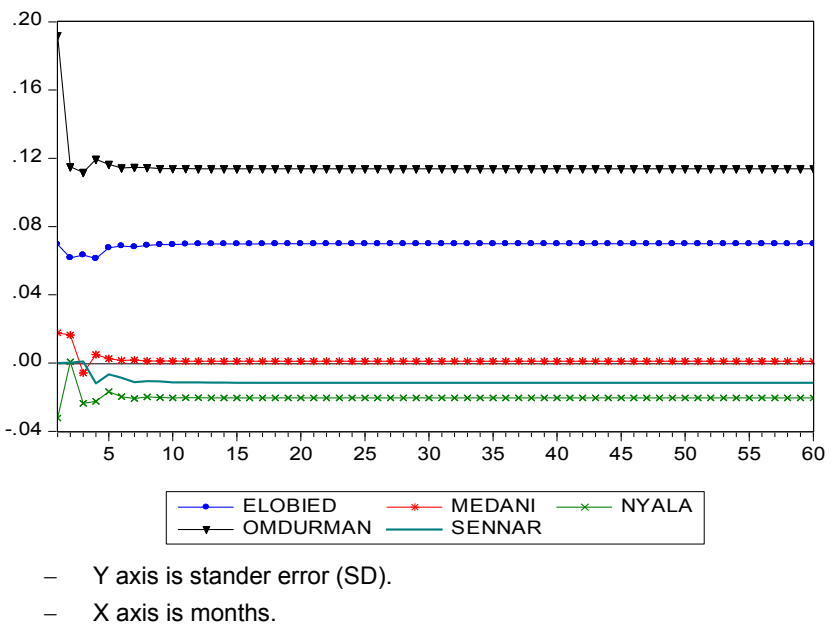

Figure 9: Generalized impulse response to one standard error shock in the equation of Sennar sheep prices $1995 \mathrm{ml}-2011 \mathrm{~m} 12$.

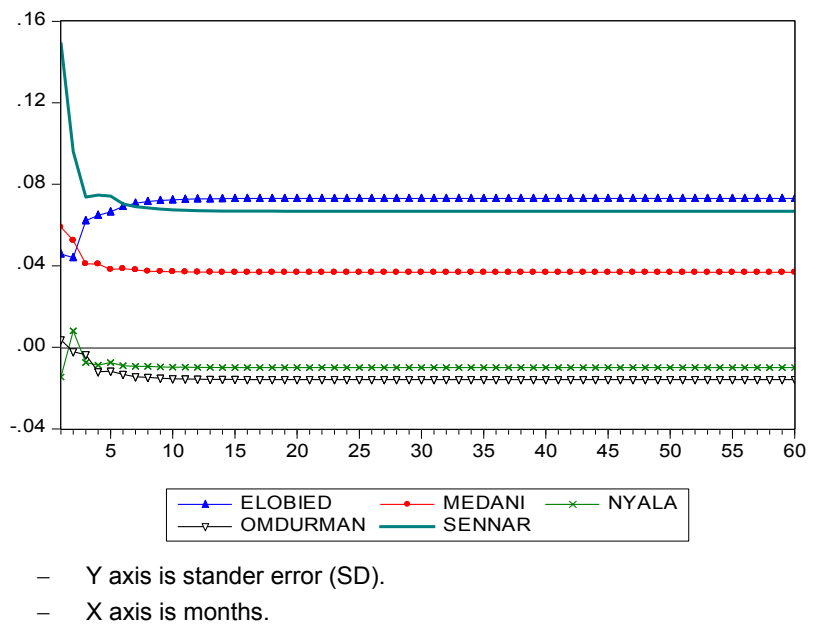

Figure 10: Generalized impulse response to one standard error shock in the equation of Nyala sheep prices $1995 \mathrm{ml}-2011 \mathrm{~m} 12$.

the characteristics of the data used in the models. The figures between brackets are the rejection probability.
When the series were drawn against time it was noticed that the time paths during 1990's were slightly different from previous years [22]. This is quite understandable because of the instability which has characterized the Sudanese economy during this period. Owing to this problem, the models for predicting the future path of its variables should be used cautiously.

\section{Impulse response approach results}

An impulse-response analysis was carried out to better understand dynamic price interrelationships, how price shocks were transmitted, and how long take for shocks to be eliminated in alternate markets. The Figures 7-10 below give response function to a price shock equal in size to one standard error in each market equation over a 36 months horizon.

Figure 7 below depicts the impulse response in Elobied, Omdurman, Sennar and Nyala markets due to one standard error price shock in Medani market. It's obvious that Omdurman and Nyala take eight months for Medani market to eliminate the price shock and converge onto long-run equilibrium, the long distance between Medani and Nyala justified this result while Omdurman associated with Medani as demand markets. Elobied and Sennar take six months to remove any disequilibrium and move back to long-run equilibrium. This result indicates that Elobied market is main source of sheep for Medani market in which toke the same period of Sennar market to eliminate prices disequilibrium.

Figure 8 below depicts a standard error shock in Elobied and its response in Medani, Omdurman, Sennar and Nyala, which shows that the adjustment take a five months to eliminate the price shock and converge onto long-run equilibrium for all markets. This result is reasonable because of short distance in case of Nyala and because Omdurman and Medani markets were considered as demand markets depend on Elobied market to supply them with sheep. Therefore, the information of sheep prices between these markets was continuous.

The Elobied, Medani, Sennar and Nyala markets, which in response to a shock in Omdurman markets. Elobied, Nyala and Sennar adjust within five months. While Medani market takes more than four months to converge onto long-run equilibrium, this justified by the short distance between these two markets.

The short period (5 months) of long-run equilibrium adjustment indicates that there are strong price linkages between the two markets (Omdurman with Elobied and Nyala markets individually) and also justifies the physical arbitrage adjusting for any disequilibrium between the two markets.

Figure 9 below depicts a standard error shock in Sennar and its response in Elobied, Omdurman, Medani, and Nyala markets. In response to a standard error shock in Sennar market, the above mentioned that Omdurman, Medani, and Nyala markets adjusted within four months which means there was a strong relationship among Sennar market and these sheep markets. Elobied market adjusted within five months, this may due to the same nature of these two markets as supply markets.

Figure 10 below depicts a standard error shock in Nyala and its response in Elobied, Omdurman, Medani and Sennar markets, which shows that the adjustment take four months to eliminate the price shock and converge onto long-run equilibrium for Elobied, and Medani markets. The close production areas of Nyala and Elobied justified this result for the easy information movement. Omdurman and Sennar 


\begin{tabular}{|l|l|l|l|}
\hline Direction & Obs & F-Statistic & Prob. \\
\hline Medani does not granger cause Elobied & 202 & 0.89835 & 0.4089 \\
\hline Elobied does not granger cause Medani & & 2.23947 & 0.1092 \\
\hline Nyala does granger cause Elobied & 202 & 4.14190 & 0.0173 \\
\hline Elobied does granger cause Nyala & & 4.67885 & 0.0103 \\
\hline Omdurman does granger cause Elobied & 202 & 2.51226 & 0.0837 \\
\hline Elobied does not granger cause Omdurman & & 1.81085 & 0.1662 \\
\hline Sennar does not granger cause Elobied & 202 & 0.38267 & 0.6825 \\
\hline Elobied does granger cause Sennar & & 2.41048 & 0.0924 \\
\hline Nyala does granger cause Medani & 202 & 5.62191 & 0.0042 \\
\hline Medani does granger cause Nyala & & 2.82837 & 0.0615 \\
\hline Omdurman does not granger cause Medani & 202 & 1.50213 & 0.2252 \\
\hline Medani does not granger cause Omdurman & & 0.32690 & 0.7215 \\
\hline Sennar does not granger cause Medani & 202 & 0.29589 & 0.7442 \\
\hline Medani does not granger cause Sennar & & 1.67032 & 0.1908 \\
\hline Omdurman does not granger cause Nyala & 202 & 1.14918 & 0.3190 \\
\hline Nyala does granger cause Omdurman & & 4.14921 & 0.0172 \\
\hline Sennar does not granger cause Nyala & 202 & 0.43247 & 0.6495 \\
\hline Nyala does granger cause Sennar & & 3.06879 & 0.0487 \\
\hline Sennar does not granger cause Omdurman & 202 & 0.10697 & 0.8986 \\
\hline Omdurman does not granger cause Sennar & & 0.45528 & 0.6349 \\
\hline
\end{tabular}

Table 10: Pairwise granger causality tests.

market takes more than six months to eliminate the price shock and converge onto long-run equilibrium, the interpretation behind this may due to the long distance between Nyala and these two markets.

\section{Pairwise granger causality analysis for sheep prices}

Granger causality is also estimated between pairs of livestock markets in Sudan during the period of study. Granger causality means the direction of price formation between two markets and related spatial arbitrage, i.e., physical movement of the commodity to adjust for these prices differences. If markets located in sheep production areas, tended to Granger-cause prices in major consumption markets, this is taken as evidence that price movements were primarily driven by supply shocks. If, however, terminal markets tended to Grangercause other markets, this is taken as evidence that price movements are caused by demand shocks. Table 10 given the results of the Granger causality test.

Table 10 above show that, Medani, Elobied, Omdurman, Sennar and Nyala markets exert a causality relations, which was Nyala market created unidirectional relation causality through Medani and Elobied markets. That mean the sheep price of Nyala granger cause Medani and Elobied an on the other hand, the sheep price of Medani and Elobied granger cause Nyala. There were bidirectional relations which were Elobied market granger cause Sennar while Nyala granger causes Omdurman and Sennar, also Omdurman granger cause Elobied. Mention these results, Nyala market granger cause all other markets. The short run dynamics analysis of sheep prices holds significance results that Nyala sheep prices affecting Sennar, Medani and Omdurman markets. Nyala market as terminal market located in production area granger cause Medani and Omdurman as major consumption markets; this was taken as evidence that price movements were primarily driven by supply shocks. That mean the system was centered on Nyala i.e. Nyala could be considered as a supply of sheep market which means the prices were supply driven.

\section{Concluding Remarks}

This paper discusses the multivariate cointegration regression results for sheep prices using (Engle and Granger) test [23] and the vector autoregression (VAR) of Johansen. The first step toward cointegration tests is the stationarity tests using three approaches; these were Dickey-Fuller test, Phillips Perron test and panel unit root test. The results show that all price series are non-stationary in level, while they are stationary in first differences for all variables and then all prices were integrated of order $I(1)$. Hence these series could be tested for the existence of a long run (cointegration) relationship between them through multivariate cointegration approaches.

As the long run analysis of sheep prices in selected markets indicated, a strong evidence of cointegration of pairs of markets exists. The last month disequilibrium in prices of Medani on Sennar corrected in the next month by $5 \%$, where it seems to adjust slowly towards the long-run equilibrium. On the other hand, with respect to Omdurman on Elobied prices relationship, the last month disequilibrium in prices was corrected in the next month by $15 \%$.

In the long run the level of sheep prices in Medani, Elobied, Omdurman, Sennar and Nyala exert significant long run effect on the current development of prices of Elobied and Sennar markets, thus suggesting the validity of the long run equilibrium relationship in Elobied and Sennar markets. But the levels of sheep prices in the five markets have no significant long run effect on Omdurman, Medani and Nyala prices. This result indicate that Elobied sheep markets consider as leader market, The long run analysis showed that Omdurman and Nyala markets were not cointegrated. The lack of cointegration among these markets may be due to the long distances separating the major sheep production areas from the consumption areas, the slow means of transport and the high marketing costs. The trekking route from Nyala to Elobied, for instance, is about 600 kilometers, and that between Elobied and Omdurman is about 560 kilometers, giving a total trekking route from Nyala to Omdurman of about 1,160 kilometers. The journey along this route takes 75 to 80 days, making the total marketing costs about $24 \%$ of the total costs.

In the short run the sheep prices of Nyala market does not have any impact on the rest of the prices of other markets except Medani market. Babiker [24] found that the sheep prices of Nyala market are affected by their own prices only in the short run. The prices of sheep in Elobied market affect the sheep prices in Omdurman livestock market by $33 \%$ in the short run, Elobied affect Medani by $44 \%$ Omdurman affect Elobied by 34\%, Medani affect Sennar by 36\% and Sennar affect Medani by $46 \%$. This coherent affecting of sheep prices may due to the active commercial movement between these markets because of the ease of transportation, as well as to the relatively near distances between these markets [25].

The periods that sheep markets need to eliminate the price shock and converge onto long-run equilibrium was fluctuated between four and five months. Elobied, Nyala and Sennar adjust the shock in Omdurman market within five months and converge onto long-run equilibrium, while Medani market takes four months to converge onto long-run equilibrium, this justified by the short distance between these two markets. The short period of long-run equilibrium adjustment indicated that there are strong price linkages between Omdurman and other four markets (Elobied, Medani, Sennar and Nyala markets). The prices causality indicated unidirectional relation causality of Nyala market through Medani and Elobied markets. Nyala market as terminal market located in production area granger cause Medani and Omdurman as major consumption markets; this was taken as evidence 
Citation: Mohamed Bushara OA, Abdelmahmod MKA (2016) Efficiency of Selected Sudanese Sheep Markets: A Multivariate Approach (1995-2011). Int J Econ Manag Sci 6: 389. doi: 10.4172/2162-6359.1000389

Page 10 of 10

that price movements were primarily driven by supply shocks. That mean the system was centred on Nyala i.e. Nyala could be considered as a supply market in sheep market which means the prices were supply driven.

\section{References}

1. Corporation ARS (2004) Livestock Market Statistical. Animal Resources Services Corporation.

2. Bank World (2003) World Development Report 2003: World Bank. Washington pp: 148-161.

3. Fahey, Dan, Leonard, David K (2007) The political economy of livestock and pastoralism in Sudan. Berkeley, CA: IGAD Livestock Policy Initiative International Resources Group and Institute for International Studies, University of California.

4. Corporation ARS (2010) Livestock Market Statistical Data Report 2010. Omdurman.

5. Bank World (2006) Diagnostic Trade Integration Study (DTIS) Productivity and Trade in Agricultural Products, World Bank, Sudan Study Draft.

6. Babiker NM, Bushara MOA (2006) The spatial integration of sheep markets in the Sudan: A bivariate approach. Gezira Journal of Agricultural Science 4: $147-156$

7. Idris B (2008) Livestock Marketing in Eastern and Central Sudan: Sector Policy Note, Sudan Multi Donor Trust Fund National.

8. Bushara MOA, Abdelmahmod MKA (2015) Efficiency of Selected Sudanese Cattle Markets: Multivariate Co-integration Approach (1995-2011). International Journal of Economics and Management Sciences.

9. Johansen S, Juselius K (1990) Maximum likelihood estimation and inference on cointegration with applications to the demand for money. Oxford Bulletin of Economics and Statistics 52: 169-210.

10. MacKinnon, James GH, Alfred A, Michelis L (1998) Numerical distribution functions of likelihood ratio tests for cointegration. Department of Economics, University of Canterbury.
11. Johansen S (1988) Statistical analysis of cointegration vectors. Journal of economic dynamics and control 12: 231-254.

12. Johansen S (1991) Estimation and hypothesis testing of cointegration vectors in Gausian vector autoregressive models. Economietrica 59: 1551-1580.

13. Johansen S (1995) Likelihood-based inference in cointegrated vector autoregressive models. OUP Catalogue.

14. Johansen S (1992) Determination of cointegration ranks in the presence of a linear trend. Oxford Bulletin of Economics and Statistics 54: 383-397.

15. Akaike H (1987) Factor analysis and AIC. Psychometrika 52: 317-332.

16. Hannan EJ, Quinn B G (1979) The determination of the order of an autoregression. Journal of the Royal Statistical Society. Series B (Methodological) 41: 190-195.

17. Greene, William H, Seaks Terry G (1991) The restricted least squares estimator: a pedagogical note. The Review of Economics and Statistics 73: 563-567.

18. Banerjee A, Dolado JJ, Henry G (1993) Co-integration, error correction, and the econometric analysis of non-stationary data. OUP Catalogue.

19. Idris B, Abdalla AM (2009) Spatial price transmission: A study of sheep markets in Sudan. African Journal of Agricultural and Resource Economics 3: 43-56.

20. Zohair MA (1970) Marketing of livestock in the Sudan. University for Reading.

21. Jarque CM (2011) Jarque-Bera test International Encyclopedia of Statistica Science 701-702 Springer.

22. Babiker NM, Bushara MOA (2006) Integration between cattle markets in the Sudan, 1980-2000. Gezira Journal of Agricultural Science 4: 130-146.

23. Robert FE, Clive WJG (1987) Co-integration and error correction representation, estimation, and testing. Econometrica 55: 251-276.

24. Babiker NM, Bushara MOA (2006) The Spatial Integration of Sheep Markets in the Sudan: A bivariate Approach 4: 147-156

25. David AD, Wayne AF (1981) Likelihood ratio statistics for autoregressive time series with a unit root. Econometrica 49: 1057-1072. 